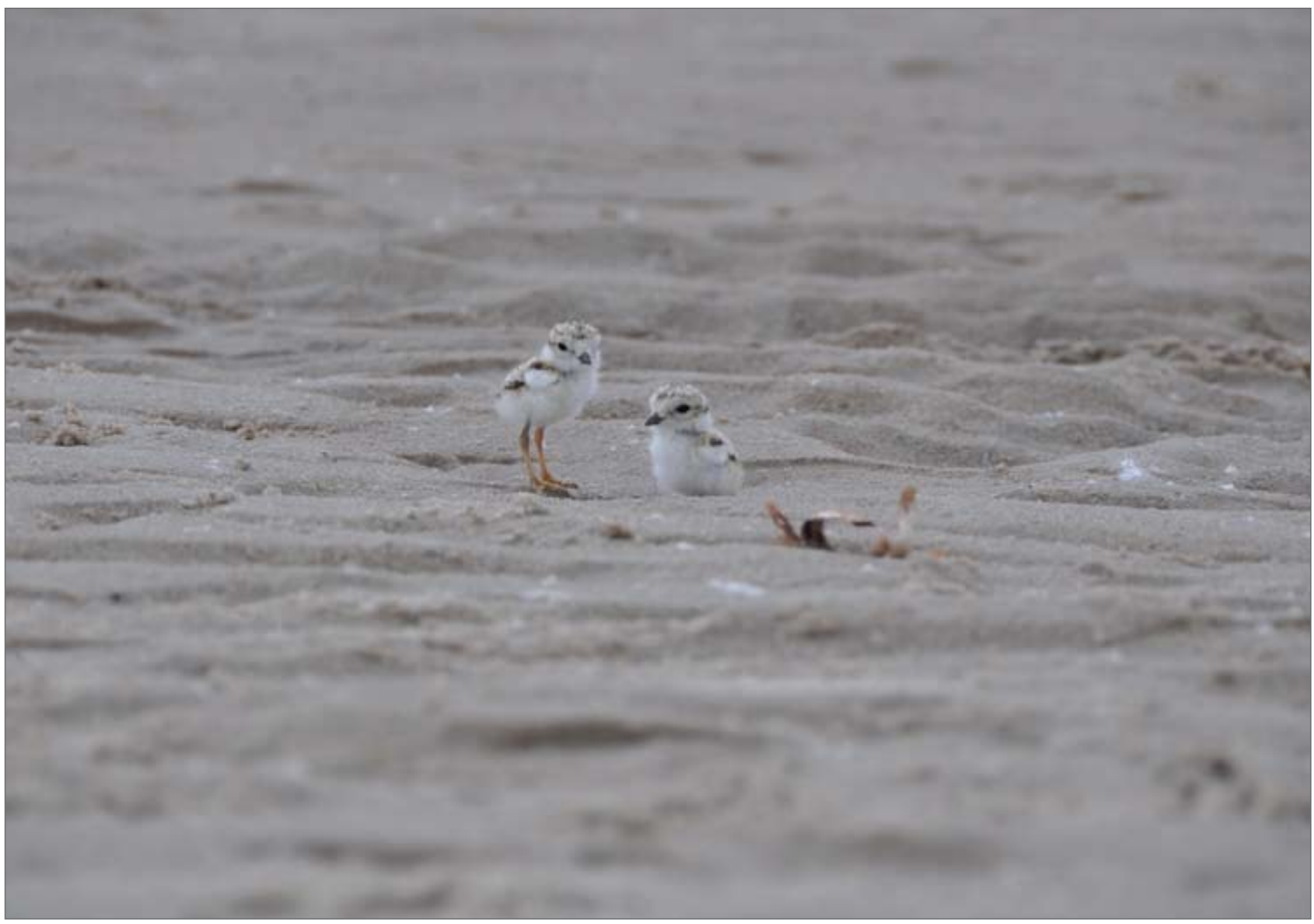

Piping Plover Chicks on Grand Beach. Photo credit: Alexandra Froese

\title{
MANITOBA'S DECLINING PIPING PLOVER POPULATION AND THE IMPORTANCE OF SPECIAL CONSERVATION AREAS
}

\section{J. Paul Goossen}

Emeritus Associate

Canadian Wildlife Service

Environment and

Climate Change Canada

123 Main Street, Suite 150

Winnipeg, MB R3C 4W2

\section{Current address:}

2-18 Fairway Drive

Morden, MB R6M 0B2

pgoossen@mymts.net

\section{Ken Porteous}

15 Palmer Place

Sandy Hook, MB ROC 2W0

kcporteous@me.com
Herbert K. Job wrote of the Piping Plover in the seminal work, Birds of America "Somehow the seabeach hardly seems fully genuine without it. None the less many of our beaches have lost this little gem of a resident". ${ }^{1}$ That was 100 years ago. Alas, now on our trip to Gull Bay on Lake Winnipeg, it had come to pass. We did not hear the plaintive 'peep-lo' call, which normally alerts the visitor of its presence before one actually sees it.

Many endangered species have a spotty distribution where local and even entire provincial populations
: can blink in and out depending on varying habitat and climatic conditions. A challenge for wildlife managers is to decide how long to continue protecting an area for a species at risk when it no longer uses the area. Such could be the case in Manitoba for habitat no longer used by the beach-nesting Piping Plover (Charadrius melodus), listed as endangered both provincially and nationally. ${ }^{2,3,4,5}$ Conservation concerns in Manitoba were first raised by Susan Haig who conducted a doctoral study on this migratory shorebird at Lake Manitoba, West Shoal Lake and Lake Winnipeg 


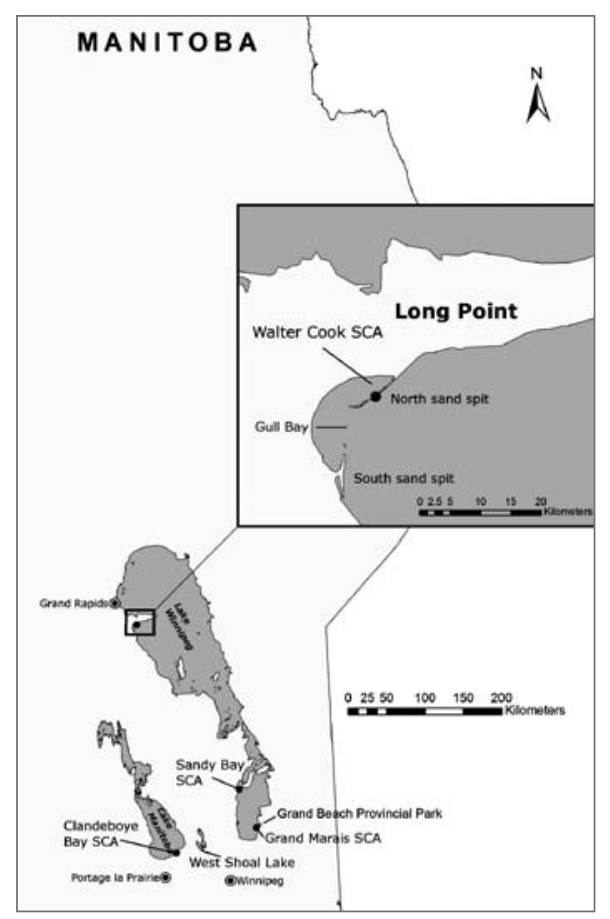

FIGURE 1. Map of Manitoba showing Special Conservation Areas for Piping Plovers.

(Fig. 1) from 1981-1986. ${ }^{6} \mathrm{Her}$ concern for the plover's future led her to identify important breeding sites for Piping Plovers in Manitoba and encouraged their protection. ${ }^{7}$ To facilitate species at risk conservation, the Manitoba government initiated a Special Conservation Area (SCA) program to protect the habitat of endangered species. Of the five SCAs established in Manitoba, that are related to species at risk, four were designated to protect Piping Plovers and their nesting habitat: Clandeboye Bay SCA (1983) (N. Firlotte, pers. comm.) in the southeast corner of Lake Manitoba, Walter Cook SCA (WCSCA) (1991) located on Lake Winnipeg's Gull Bay in central Manitoba, Grand Marais SCA (2014) and Sandy Bar SCA (2014) on Lake Winnipeg (G. Suggett, pers. comm.). ${ }^{7,89}$ Piping Plovers no longer nest at these SCAs and have disappeared from nearly all nesting sites in Manitoba. In this paper we review the recent status of Piping Plovers in Manitoba and the SCAs designated to protect the species. We also discuss efforts

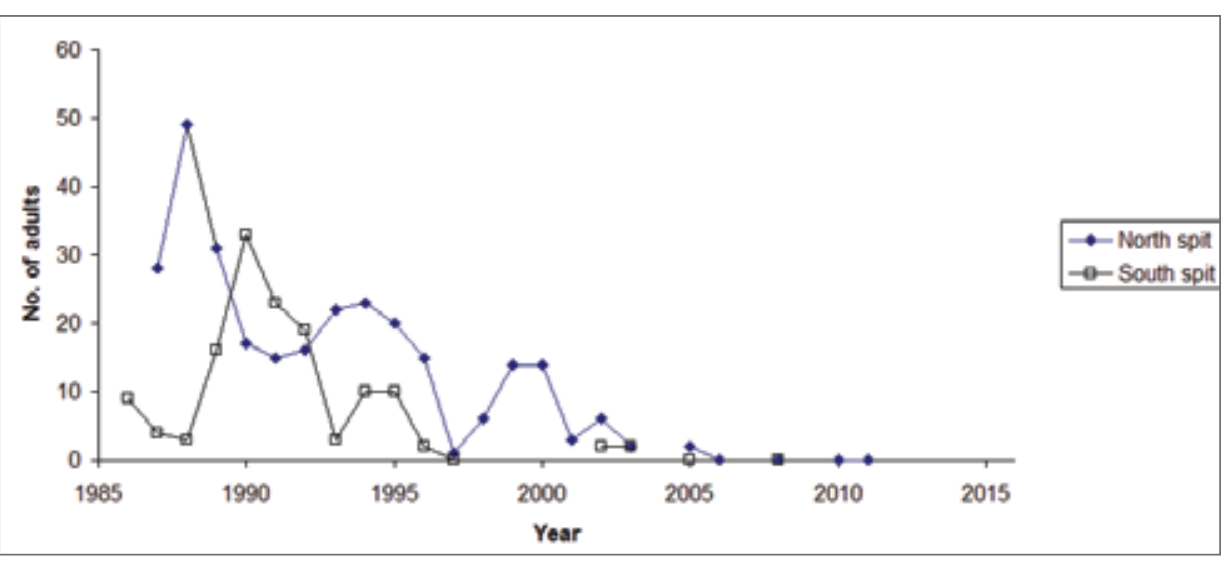

FIGURE 2. Number of Piping Plovers counted at the Gull Bay north and south spits, Lake Winnipeg (1986 -2011). 11,12,14,16,25

undertaken to protect and restore habitat on SCAs, the potential for — and possible origins of - Piping Plovers to

re-colonize former breeding sites in Manitoba and the value of SCAs for protecting endangered species habitat when the species no longer uses it.

Long Point is a relatively uninhabited forested peninsula located southeast of Grand Rapids that is up to $19 \mathrm{~km}$ wide and extends about $40 \mathrm{~km}$ east into Lake Winnipeg (Fig. 1). Immediately south of Long Point, at its base, is Gull Bay. This water body has two spits that extend into the bay, one in a northerly direction and the other southwesterly. These spits have no official names and have been referred to as bars, spits or points. ${ }^{10,11,12,13,14}$ The north spit stretches approximately $5.6 \mathrm{~km}$ into the bay while the south spit extends only $2.0 \mathrm{~km}$. The spits are separated by about $3.4 \mathrm{~km}$ of water. The spits are dynamic and affected by lake currents and water levels. In 1998, a breach near the base of the north spit resulted in the spit becoming an island. ${ }^{15}$

Recognition of the north spit in Lake Winnipeg's Gull Bay (5254'00" ; $\left.98^{\circ} 51^{\prime} 35^{\prime \prime}\right)$ is credited to Walter Cook, a fisher, trapper, naturalist and hunter from nearby Grand Rapids who initially reported the site as an important Piping Plover nesting area. ${ }^{15}$ This spit was identified as being not only important as Piping Plover habitat but also as a base for the Grand Rapids Fishermen's Co-operative's fishing operations. Thus the joint efforts of the Co-operative and the Manitoba government resulted in the establishment of the WCSCA, located on the north spit about three-quarters of the way to its tip. ${ }^{12}$

Annual Piping Plover surveys were carried out at the north spit from 1987 to 2003 but only five visits (2005, 2006, 2008, 2010, 2011) occurred from 2004 to 2016 . $^{13,14,16,17}$ Piping Plovers were surveyed yearly at the south spit from 1986 to 1997, however, from 1998 to 2016, only five surveys (2000, 2002, 2003, 2005 and 2008) were carried out. ${ }^{13,14,16,17}$ Counts from regular surveys carried out at both Gull Bay spits from 19871997 indicated Piping Plover numbers peaked at 52 adults on July 13 and 14 , 1988. ${ }^{16,18}$ During that year, 49 adults and 11 young were counted on the north spit on July 13 and three adults and three young were seen on the south spit on July $14 .{ }^{18}$ By the time the WCSCA was established in 1991, only 15 adults were observed on the north spit. ${ }^{11}$ Thereafter, plover numbers increased to 23 adults in 1994 but declined thereafter (Fig. 2). ${ }^{16,19}$ The last sighting of Piping Plovers on the north spit was in 2005 when two adults were found but no nest was located. ${ }^{13}$ 

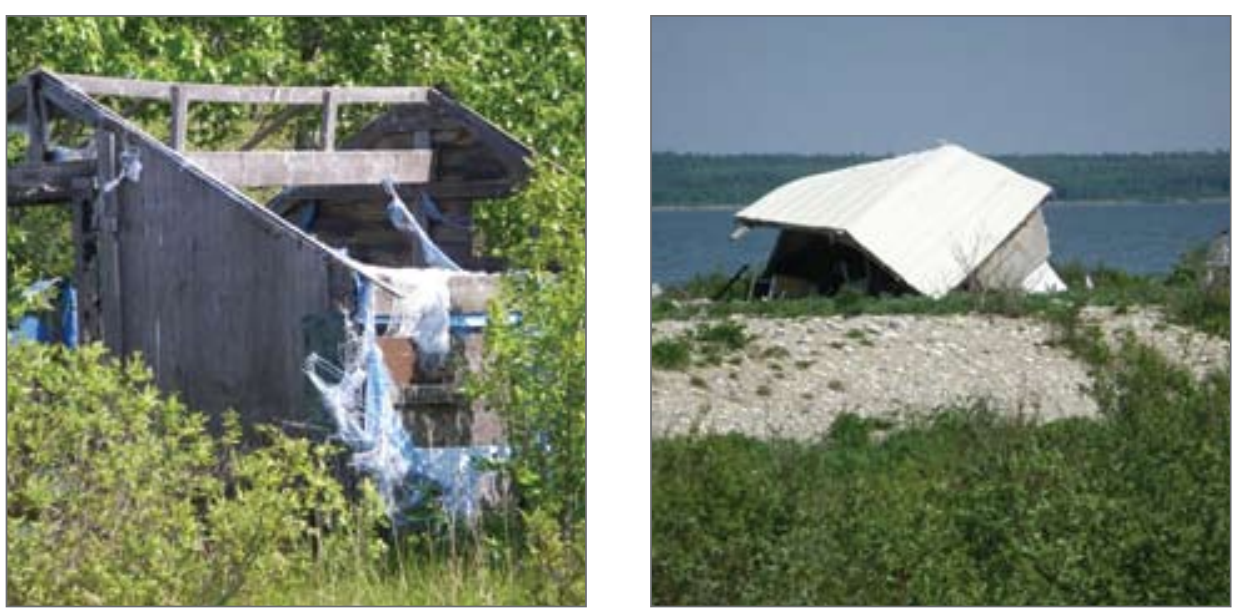

FIGURE 3. Deserted cabins at Gull Bay north spit can be havens for predators. Photo credit: Ken Porteous.

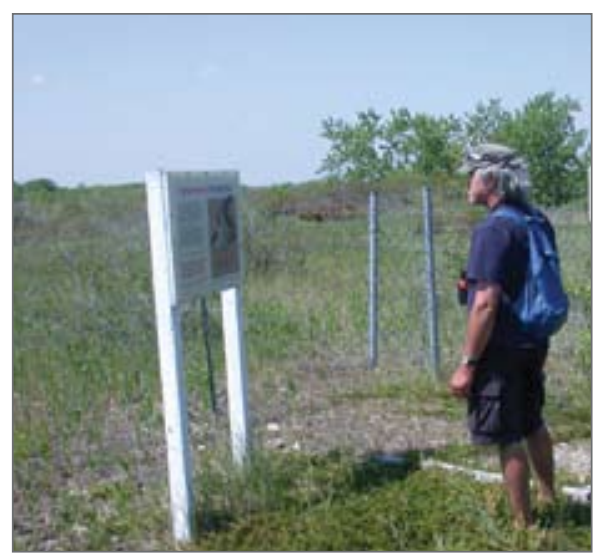

FIGURE 4. Ken Porteous reads informational sign about the Piping Plover at the Walter Cook Special Conservation Area, Gull Bay, Lake Winnipeg. Photo credit: J. Paul Goossen

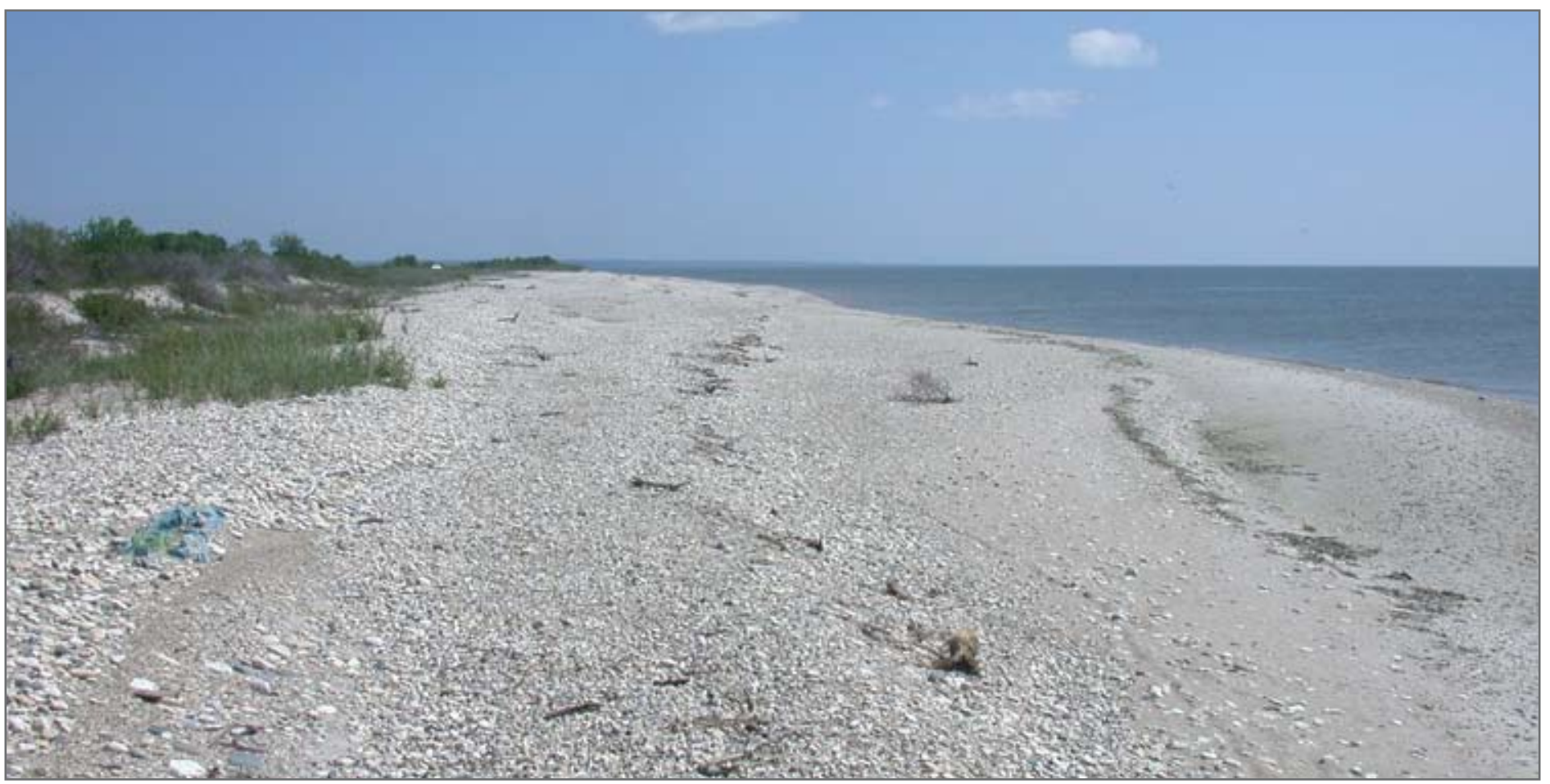

FIGURE 5. Piping Plover habitat at the Walter Cook Special Conservation Area, Lake Winnipeg. Photo credit: J. Paul Goossen

The south spit had its highest number (33) of adult plovers in 1990. ${ }^{16}$ Piping Plovers (2) were last seen on the south spit in 2003. ${ }^{16,20}$ Nesting at Gull Bay was last recorded in 2003 when one nest was found on each spit. ${ }^{16,20}$

In 2010, we organized a field trip to check the WCSCA during the Piping Plover's nesting season, to look for evidence of Piping Plovers and to assess habitat conditions. At the time, it had been five years since the last survey for that area. ${ }^{13}$ On June 16 , we accessed the north spit by wading through about $1 \mathrm{~m}$ deep water. In total, we spent about $6.75 \mathrm{~h}$ walking both sides of the spit assessing habitat suitability, looking for Piping Plovers and recording numbers of other avian species present. We did not visit the south spit.

The widest and least vegetated beaches were located on the lake side of the spit. For the most part, the bay side beach was very narrow with extensive vegetation often within 1-2 $\mathrm{m}$ from the water's edge. Much of the central portions of the spit had vegetation, including shrubs (e.g., willows) and a few small trees (aspen).
At least 18 fisher cabins/buildings were located on the spit; these were all northeast of the SCA, generally on the bay side of the spit. No human activity was noted on that date and some buildings were obviously abandoned (Fig. 3). We saw no evidence of All Terrain Vehicle (ATV) activity which has been noted during previous surveys and recognized for its potential impact on Piping Plovers. ${ }^{14,18,21}$

The original fencing and signage for the WCSCA (Fig. 4) was still mostly in place but weathered from 19 years of exposure. Fencing still 
extended to the bay side shore of the spit, however, not onto the lake side shore. Fairly extensive Piping Plover breeding habitat was still present on the lake side of the spit including within the WCSCA (Fig. 5). On this date, this habitat was essentially vegetation-free and appeared wide enough and sufficiently elevated from the water to be suitable for use by plovers. However, a storm event could result in this beach being washed over. Unfortunately, no Piping Plovers were located in the WCSCA nor other parts of the spit during our visit.

\section{Factors related to abandonment}

Several factors have been suggested to account for the rather precipitous decline of Piping Plovers at Gull Bay. These include the longterm effects of stabilized water levels on Lake Winnipeg and the presence of humans and nesting larids. ${ }^{14}$

The management of water levels on reservoirs, lakes and rivers in the Northern Great Plains poses significant challenges to protecting and maintaining Piping Plover habitat. ${ }^{3,5}$ Prior to establishment of dams and water management strategies, beaches, islands and spits were subjected to the impact of highly variable water levels. In low water years, beaches and spits became wider providing greater habitat availability for nesting plovers. In high water years, nesting and brood habitats were reduced or were unavailable and nesting plovers may have had to relocate to alternate nesting areas in those years. One positive result of the high water was the scouring effect it had on vegetation that encroached on plover habitat. Reducing or eliminating this vegetation in high water years resulted in restoration or even expansion of habitat in years

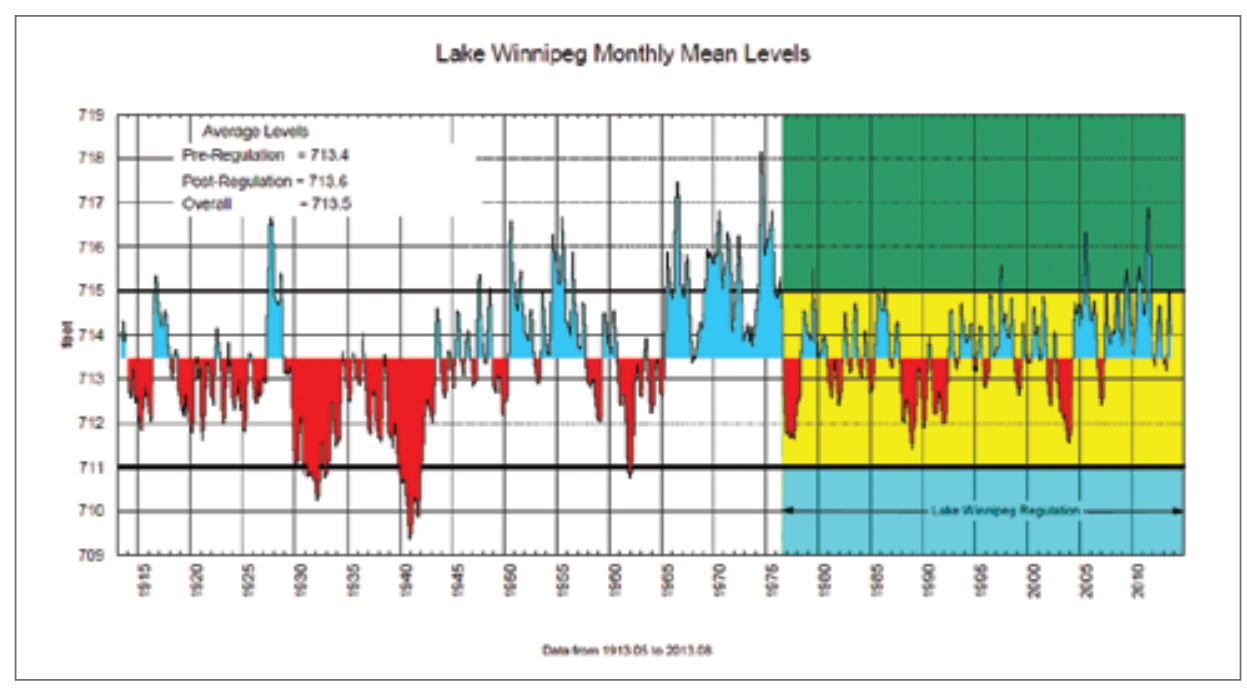

FIGURE 6. Lake Winnipeg average water levels during unregulated and regulated periods. ${ }^{24}$

when water levels were lower. ${ }^{22}$ Also, suitable material (e.g., sand or gravel) deposited on nesting beaches during high water events helped improve the quality of these nesting beaches for Piping Plovers.

Lake Winnipeg's water levels have been regulated since 1976.23,24 Even though average water levels of Lake Winnipeg differ by only $0.2 \mathrm{~m}$ when comparing pre- and post- regulation, the amplitude and frequency of low and high water levels have been greatly reduced (Fig. 6). ${ }^{23}$ As a result of this long-term stabilization, vegetation has established on former nesting beaches and spits narrowing beach widths and reducing the potential habitat for Piping Plovers. Similarly, vegetation encroachment on Lake Manitoba beaches used by Piping Plovers is considered to be related to water level stabilization. ${ }^{11}$

Displacement is another possible factor contributing to the decline of Piping Plovers at Gull Bay as gull and tern colony expansion appears to have encroached on former plover nesting habitat. ${ }^{25}$ Gulls are known or suspected predators of Piping Plover eggs and chicks. ${ }^{26}$ Herring Gulls (Larus argentatus) had previously been reported nesting on the north spit in 1979 and 1999 but in relatively low numbers (50-60+). 15,27
In 1999, more than 2,000 breeding pairs of Ring-billed Gulls (Larus delawarensis) were also observed on the spit and in $2000,3,750$ nests (7,500 adults) were recorded (W. Koonz, unpubl. data). ${ }^{15}$

During our 2010 survey of the spit, we counted an estimated 5,400 Ring-billed Gulls in 10 locations along the spit ranging in numbers from 100 to 2,000 adults (Fig. 7). At most of these locations we found gull nests with eggs. The majority of gull nests observed contained three eggs (range $=1-4$ ), however, some had one or two downy chicks. The majority of gulls nested away from the WCSCA itself and also more toward the bay half of the spit. We also estimated that about 1,200 Common Terns (Sterna hirundo) were present, fewer than the 2,000 pairs reported in 1999. ${ }^{15}$ Most tern nests had three eggs (range $=1-4$ eggs). Although a few Caspian Terns (Hydroprogne caspia) were also observed ( 55), we saw no evidence of breeding. A family of Common Ravens (Corvus corax) (two adults and two fledged young) and a domestic dog were also observed on the spit. At one location just offshore of the SCA we located an abandoned fishing net with dead fish, an attraction for scavengers and 


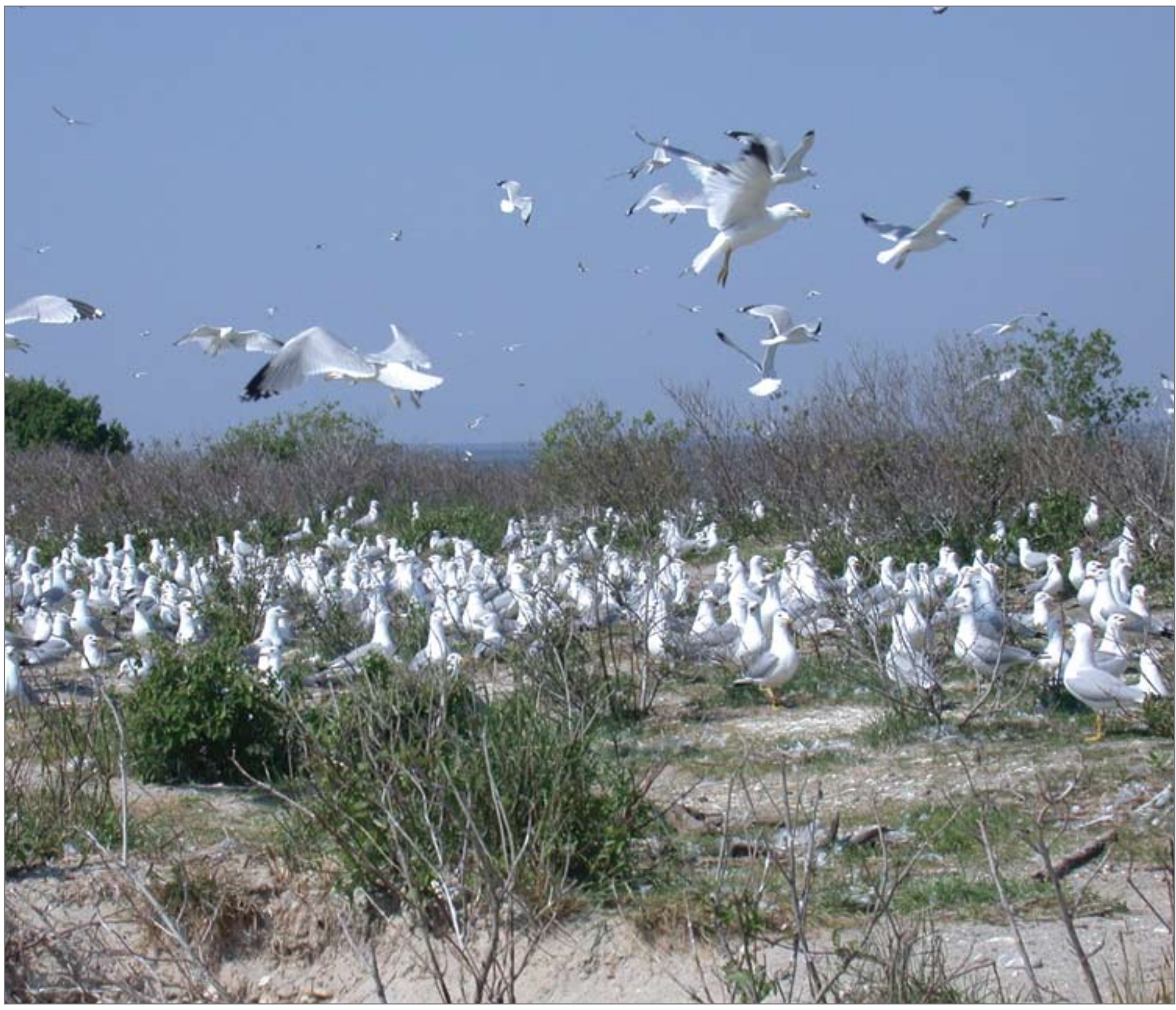

FIGURE 7. Ring-billed Gull colony near the Walter Cook Special Conservation Area, Lake Winnipeg. Photo credit: J. Paul Goossen

predators. Although no raccoons (Procyon lotor) were seen, the abandoned cabins may well provide shelter for these and other potential mammalian predators.

\section{Population decline}

Manitoba's Piping Plover population is precariously close to extirpation. The population has declined from a high of 137 adults in 1990 to three in 2016. ${ }^{16,28}$ From 2013-2015, no Piping Plovers were found in Manitoba although it is possible that some may have nested in more remote areas or at beaches that were not surveyed. The number of breeding locations with Piping Plovers has also greatly declined in Manitoba over the past 30 years. During this period, Piping Plovers nested at 21 sites but by 2016 Piping Plover nesting locations were down to one site (K. Porteous, pers. observ.). ${ }^{29}$

Beginning in 1995, higher than usual precipitation levels in much of southern Manitoba have reduced Piping Plover nesting habitat at many of the best former nesting sites in Manitoba. ${ }^{12,25}$ For example, prime breeding habitat at West Shoal Lake, about $55 \mathrm{~km}$ northeast of Portage la Prairie, has been flooded and is now under several metres of water. ${ }^{15,25}$ Once harbouring the largest nesting population in the province with a count of 67 adults in 1994, Piping Plovers last successfully nested at West Shoal Lake in 1997, and since 2000 , plovers have not been recorded at this site. ${ }^{16,25}$ Should more normal precipitation result in drawdown of water levels at West Shoal Lake, Piping Plovers may again select this site for nesting. Higher than normal water levels may also have contributed to declines at 
other major nesting areas on Lake Manitoba (Clandeboye Bay) and Lake Winnipeg (Grand Beach, Grand Marais and Gull Bay), although long-term effects of water level stabilization on these lakes may be even more damaging. Piping Plover numbers have also decreased at the Gull Bay spits.

Some but not all Piping Plovers breed in their first year and return, although in small numbers, to or near their natal sites. ${ }^{6,30}$ Haig and Oring found breeding site fidelity for adult Piping Plovers returning to Manitoba to be relatively high at $67.7 \% .{ }^{6}$ Natal philopatry, or chicks returning to hatch sites in Manitoba, was much lower at $5.5 \%$. The return rate climbed to $12.2 \%$ if chicks returning to the local area were included. ${ }^{6}$ These low return rates of chicks to Manitoba may explain why only two of 12 chicks banded at Grand Beach and Gimli during 20092011 have been sighted again in the province. $^{31}$

Piping Plovers that nest or are raised in Manitoba may disperse elsewhere in North America rather than returning to their natal or breeding sites. A chick originally hatched in 1985 at West Shoal Lake, Manitoba, was re-sighted at Long Point, Lake Erie, Ontario in August 1986. ${ }^{6}$ This bird may have been a migrant (S. Haig, pers. comm.), as its summering location and breeding status was unknown. More concrete evidence of such longdistance movements, however, was provided by a chick banded in 2009 at Grand Beach, Manitoba that was seen at Lake Superior near Grand Marais, Michigan in 2010 and was later documented breeding at Lake Michigan, near Port Inland, Michigan from 2011-2015 (A. Van Zoeren and S. Saunders, pers. comm.).

Piping Plovers can repopulate breeding locations which have been abandoned for many years as evidenced by the return of Piping Plovers to the Great Lakes region. ${ }^{32}$ However, the question arises as to where might Piping Plovers come from to repopulate Manitoba breeding sites? Piping Plovers from the Atlantic coast subspecies (C. $m$. melodus) have never been observed in the Great Lakes (F. Cuthbert, pers. comm. but see Miller et al.33) and Northern Great Plains (D. Catlin, pers. comm.) regions although the two subspecies (C. m. circumcinctus) occasionally winter along the same coasts. ${ }^{6,33}$ Piping Plovers from the Great Lakes are not known to breed in the central Northern Great Plains (F. Cuthbert, pers. comm.) and so are another doubtful source.

Piping Plovers from Lake of the Woods, Minnesota that were seen in Manitoba during 1984-1987 suggest Lake of the Woods as a potential source. ${ }^{6}$ Three breeding adults from Lake of the Woods were seen in Manitoba (Clandeboye Bay, Long Point (Gull Bay) and West Shoal Lake). This scenario is somewhat restrictive as the Lake of the Woods population is nearly extirpated. Only four adults were counted at Lake of the Woods during the 2011 international census and none during the 2016 international census although a pair was observed prior to the census (E. Elliott-Smith, pers. comm.). 32,34

Recruitment of Piping Plovers from parts of the Northern Great Plains as they overfly nesting areas or pass through Manitoba on their spring migration is another possible option. However, evidence for this occurring is minimal as only two Piping Plovers banded outside of Manitoba but within the central Northern Great Plains has ever been observed at any of the Manitoba sites surveyed. In 1991, a banded Piping Plover with a green flag was observed on Gull
Bay's north spit. ${ }^{35}$ The green flag indicates that the bird was banded in the US Northern Great Plains (either North Dakota or Lake of the Woods). ${ }^{36}$ On June 24, 2016, a Piping Plover, possibly banded in North Dakota (M. Ring, pers. comm.), was observed at Whitewater Lake in southwestern Manitoba (P. Taylor, pers. comm.). Long distance movements of Piping Plovers from the Northern Great Plains, within and outside their regional population ranges, lends further credence to the potential for repopulating Manitoba sites. A chick from South Dakota was documented breeding at Lake of the Woods in its second year (D. Catlin, pers. comm.) and a Great Lakes plover was located breeding in South Carolina, along the U.S. Atlantic coast. $^{37}$

\section{Habitat Restoration and Creation}

The challenge to protect and restore habitat for Piping Plovers in Manitoba is ongoing and may be delayed or set back by current climatic conditions. SCAs that were designed to protect Piping Plovers in Manitoba continue to serve a purpose, despite a prolonged absence of the species that the SCAs were originally created for. They are a reminder that even significant conservation efforts to protect important habitat may not be enough to ensure recovery for species at risk. In some instances, wildlife managers need to wait until climatic conditions are suitable to allow a species to return. In others, habitat restoration or creation through direct human intervention may be needed to modify or provide additional nesting habitat for Piping Plovers. These efforts, even when successful, may be temporary and sometimes are unsustainable in the long-term especially when unsuitable climatic conditions intervene. 
Several attempts have been made to create or restore Piping Plover habitat in Manitoba. Initial attempts involved creating artificial habitat on a Lake Manitoba beach near Delta in 1983 and 1984. Tree saplings along the beach ridge were extricated. Gravel was put down at $20 \mathrm{~m}$ intervals on a $25 \mathrm{~m}$ by $2 \mathrm{~km}$ stretch of sand beach after the strip was ploughed. Unfortunately, a storm destroyed the newly created habitat and the nesting efforts of a Piping Plover pair attracted to this habitat. ${ }^{7}$ The creation of offshore nesting islands at West Shoal Lake in 1992, 1993 and 1995 offered plover pairs an alternative to shoreline beaches which were occasionally impacted by cattle, horses and wind tides. ${ }^{12,38}$ In total, 14 Piping Plover nests were found on two of the three islands from 1994-1996. ${ }^{12}$ Rising water levels after 1996, however, flooded out all shoreline habitat as well as the artificial islands. $15,16,21,25$

Vegetation removal at nesting beaches has been employed at locations on lakes Manitoba (near Delta, "Stony Beach") and Winnipeg to keep nesting areas free of extensive plant growth. 7,10,14,39,40,41 At Grand Beach, for example, several upper beach areas that had patches of willows and various forbs were cleared with the aid of a small bulldozer as it was felt that vegetation encroachment was impacting not only existing territories but also limiting the opportunities for additional pairs to establish territories. Although this endeavour succeeded in rehabilitating a couple of former nesting sites that were eventually used by nesting plovers, efforts to create new nesting areas were less successful as the deep roots of the willows could not be completely removed and new willow growth was evident in these areas the following spring. These efforts pointed out that without annual removal of these roots and any new vegetation growth, sites tended to become re-vegetated in a year or two. Likewise, application of the herbicide (Garlon 3A) and subsequent removal of affected vegetation on a formerly occupied spit at Grand Marais in 2009 failed as the area rapidly re-vegetated. ${ }^{39,40}$

\section{Conclusion}

One of the most important values of SCAs is that they provide a measure of habitat protection for species at risk in the interim when populations are small or absent. Providing that the habitat is maintained naturally or through management efforts, these areas provide available habitat when and if the species returns to breed. When applied to Piping Plovers, the approach to managing plover habitat on SCAs needs to be viewed as a long-term endeavour. Not only does it require that nesting plovers return to and find suitable habitat at these former breeding sites, but it requires growth of these small populations to rebuild themselves to sustainable levels. The successful return of nesting pairs after a long absence in the Great Lakes show that nesting areas can eventually be recolonized. ${ }^{32}$ Since banding data has also revealed a population link between Lake of the Woods and Manitoba, this suggests the recovery of the Lake of the Woods population could eventually spill over and lead to recolonization of sites in Manitoba. The successful nesting of a single pair of Piping Plovers in Manitoba in 2016 (C. Artuso, pers. observ.) provides conservationists with a measure of hope that this endangered shorebird may in time re-establish itself in the province, including SCAs that were established for its protection.

\section{Acknowledgements}

The authors wish to thank R.E. Jones and the Portage Natural History Group for administration of grants and disbursements. We thank K. De Smet (Manitoba Sustainable Development), S.M. Haig (Oregon State University, A. Mckellar (Canadian Wildlife Service) and an anonymous reviewer for their helpful review of the manuscript and $\mathrm{G}$. Turney (Canadian Wildlife Service) for preparing the map. We also thank D. Catlin (Virginia Tech), F. Cuthbert (University of Minnesota), E. ElliottSmith (U. S. Geological Survey), Cheri Gratto-Trevor (Environment and Climate Change Canada), C. Herwig (Minnesota Department of Natural Resources), G. Suggett (Manitoba Sustainable Development) and S. Wilson (Environment and Climate Change (anada) for responding to our requests for information.

1. Job HK (1936) Piping Plover. Pearson TG (ed. in chief) Birds of America. Garden City Publishing Company, Inc. Garden City, NY. p. 264-265.

2. Manitoba Sustainable Development (2017) Species at Risk. Species listed under The Endangered Species and Ecosystems Act. Retrieved from www.gov.mb.ca/sd/wildlife/ sar/sarlist.html.

3. COSEWIC (2013) COSEWIC assessment and status report on the Piping Plover circumcinctus subspecies (Charadrius melodus circumcinctus) and the melodus subspecies (Charadrius melodus melodus) in Canada. Committee on the Status of Endangered Wildlife in Canada. Ottawa. 39 pp. Retrieved from www.registrelepsararegistry.gc.ca/ default_e.cfm).

4. Government of Canada (2017) Species at Risk Public Registry. Retrieved from http:// sararegistry.gc.ca/species/schedules_e. cfm?id=1.

5. Environment Canada (2006) Recovery strategy for the Piping Plover (Charadrius melodus Circumcinctus) in Canada. Species at Risk Act Recovery Strategy Series. Environment Canada, Ottawa.

6. Haig SM, Oring LW (1988) Distribution and dispersal in the Piping Plover. Auk 105:630-638. 
7. Haig SM (1987) Piping Plovers in Manitoba - a status report on the species and initial recovery plan for the province. In: Holroyd GL, McGillivray WB, Stepney PHR, Ealey DM, Trottier GC, Eberhart KE (eds). Proceedings of the workshop on endangered species in the Prairie Provinces. Provincial Museum of Alberta Natural History Occasional Paper No. 9. Edmonton, AB. p. 243-247.

\section{Manitoba Government (1991)}

Conservation area established to protect Piping Plovers. http://news.gov.mb.ca/news/ archives/1991/04/1991-04-25. conservation area_established_to_protect_piping_plovers. pdf.

9. Manitoba Government (2014) The Wildlife Act. Designation of Wildlife Lands Regulation, amendment. https://web2.gov.mb.ca/laws/ regs/annual/2014/172.pdf.

10. Moszynski R, Koonz WH, De Smet K (1988) Manitoba Piping Plover survey, 1987. Unpublished Manitoba Natural Resources Manuscript Report No. 88-03. Winnipeg, MB

11. Koonz WH (1994) The 1991 Piping Plover census in Manitoba. In: Flemming SP (ed). The 1991 International Piping Plover Census in Canada. Canadian Wildlife Service Occasional Paper No. 82. p. 32-34.

12. Asmundson JD, Jones RE (2004) The 1996 Piping Plover census in Manitoba. In: Goossen JP, Amirault DL (eds). The 1996 International Piping Plover Census in Canada. Technical Report Series No. 416. Canadian Wildlife Service, Edmonton, AB and Sackville, NB. p. 71-80.

13. Maconachie T (2006) Manitoba Piping Plover Stewardship Program 2005 program report. Unpublished report. Winnipeg, MB.

14. Sylvestre N, De Smet K (2010) The 2006 Piping Plover census in Manitoba. In: Goossen JP, Amirault-Langlais DL (eds). The 2006 International Piping Plover Census in Canada. Technical Report Series No. 490. Canadian Wildlife Service (Environment Canada), Edmonton, AB and Sackville, NB. p. 85-93.

15. Koonz B (2000) Some bird observations in Manitoba in 1999. Blue Jay 58:65-68.

16. Miller A (2006) The Manitoba Piping Plover Stewardship Project: a provincial strategy for the management of the endangered Piping Plover (Charadrius melodus circumcinctus). Master of Environment thesis. University of Manitoba, Winnipeg, MB.

17. Froese A (2009) Manitoba Piping Plover Stewardship Program 2008 program report. Unpublished Manitoba Conservation report. Winnipeg, MB.
18. Koonz, W (1988) Piping Plover observations Manitoba 1988. Unpublished Manitoba Department of Natural Resources report. Winnipeg, MB.

19. Jones RE (1994) Piping Plover - 1994. Unpublished preliminary report.

20. Miller A (2003) Manitoba's 2003 Piping Plover survey and productivity summary. Unpublished report. Winnipeg, MB.

21. De Smet K, Koonz B (2002) The 2001 International Piping Plover Census in Manitoba. In: Ferland CL, Haig SM 2001 International Piping Plover Census. U.S. Geological Survey, Forest and Rangeland Ecosystem Science Center, Corvallis, OR. p. 219-222.

22. Porteous K (2012) 2012 Manitoba Piping Plover Recovery Team summer activities summary. Unpublished report. Winnipeg, MB.

23. Manitoba Hydro (2017) Lake Winnipeg monthly mean levels. Retrieved from www. hydro.mb.ca/corporate/water_regimes/ lake_winnipeg_means.pdf.

24. McGinn RA, Paton WHN (2007) Lake Winnipeg. In: Boyens I (managing ed). The Encyclopedia of Manitoba. Great Plains Publications, Winnipeg, MB. p. 383-384.

25. Stewart J, DeSmet K (2005) The 2001 Piping Plover census in Manitoba. In: Amirault DL (ed) The 2001 International Piping Plover Census in Canada. Technical Report Series No. 436. Canadian Wildlife Service, Atlantic Region. p. 69-74.

26. Ivan JS, Murphy RK (2005) What preys on Piping Plover eggs and chicks? Wildlife Society Bulletin 33:113-119.

27. Koonz WH, Rakowski PW (1985) Status of colonial waterbirds nesting in southern Manitoba. Canadian Field-Naturalist 99:1929.

28. Porteous K (2016) 2016 International Piping Plover Breeding Census Manitoba Assessment. Unpublished Manitoba Sustainable Development report. Winnipeg, MB.

29. Goossen JP, Westworth SM, Yee B, Thorson D, Michaud I (2000) Atlas of Piping Plovers in the Canadian Prairie Provinces and Ontario. Multimedia CD- ROM atlas produced by Environment Canada, Edmonton and Regina.

30. Gratto-Trevor CL, Goossen JP, Westworth SM (2010) Identification and breeding of yearling Piping Plovers. Journal of Field Ornithology 81:383-391.
31. Hewson S (2011) Piping Plover

Stewardship Program report. Unpublished Manitoba Conservation report. Winnipeg, MB

32. Mackenzie SA (2015) The 2011 International Piping Plover Breeding Census in Ontario. In: Elliott-Smith E, Bidwell M, Holland AE and Haig SM Data from the 2011 International Piping Plover Census: U.S. Geological Survey Data Series 922. p. 215-220. Retrieved from http://dx.doi. org/10.3133/ds922.

33. Miller MP, Haig SM, Gratto-Trevor CL, Mullins TD (2010) Subspecies status and population genetic structure in Piping Plover (Charadrius melodus) Auk 127:57-71. U. S.

Fish and Wildlife Service (1988) Great Lakes and Northern Great Plains Piping Plover Recovery Plan. U. S. Fish and Wildlife Service, Twin Cities, MN. 160 pp.

34. Haws K (2015) The 2011 International Piping Plover Breeding Census in Minnesota In: Elliott-Smith E, Bidwell M, Holland AE and Haig SM Data from the 2011 International Piping Plover Census: U.S. Geological Survey Data Series 922. p. 221-223. Retrieved from http://dx.doi.org/10.3133/ds922.

35. Koonz WH (1991) Piping Plover report for Manitoba. Unpublished Manitoba Department of Natural Resources report. Winnipeg, MB.

36. U.S. Fish and Wildlife Service (1988) Great Lakes and Northern Great Plains Piping Plover Recovery Plan. U.S. Fish and Wildlife Service, Twin Cities, MN.

37. Hillman MD, Karpanty SM, Fraser JD, Cuthbert FJ, Altman JM, Borneman TE, Derose-Wilson A (2012) Evidence for long-distance dispersal and successful interpopulation breeding of the endangered Piping Plover. Waterbirds 35:642-644.

38. Jones R, Koonz B (1997) Piping Plover - 1997 Manitoba. Unpublished Manitoba Department of Natural Resources report.

39. Froese A (2009) 2009 Manitoba Piping Plover Recovery Project summary report. Unpublished Manitoba Conservation report. Winnipeg, MB.

40. Froese A (2010) 2010 Manitoba Piping Plover Recovery Team summer activities summary. Unpublished Manitoba Conservation report. Winnipeg, MB.

41. Smith J (2017) A look back at Important Bird and Biodiversity Area IBA MB091 Riverton Sandy Bar 2016 - Guest Blog. Retrieved from https://importantbirdareasmb. ca/2017/02/02/a-look-back-at-important-birdand-biodiversity-area-iba-mb091-rivertonsandy-bar-2016-guest-blog/. 